\title{
Sponges from rhodolith beds surrounding Ustica Island marine protected area (southern Tyrrhenian Sea), with a comprehensive inventory of the island sponge fauna
}

\author{
Caterina Longo, Giuseppe Corriero, Frine Cardone, Maria Mercurio, Cataldo Pierri, \\ Carlotta Nonnis Marzano
}

University of Bari Aldo Moro, Department of Biology, Via Orabona 4, 70125 Bari, Italy.

(CL) E-mail: caterina.longo@ uniba.it. ORCID iD: https://orcid.org/0000-0003-3123-1568

(GC) E-mail: giuseppe.corriero@uniba.it. ORCID iD: https://orcid.org/0000-0002-4076-5804

(FC) E-mail: frine.cardone @ uniba.it. ORCID iD: https://orcid.org/0000-0002-8999-8254

(MM) E-mail: maria.mercurio@ uniba.it. ORCID iD: https://orcid.org/0000-0001-5567-6380

(CP) (Corresponding author) E-mail: cataldo.pierri@uniba.it. ORCID iD: https://orcid.org/0000-

0002-6125-3322

(CNM) E-mail: carlotta.nonnismarzano@uniba.it. ORCID iD: https://orcid.org/0000-0003-1284-9610

Summary: The sponge fauna colonizing rhodolith beds from Ustica Island marine protected area was studied. Moreover, an inventory of the sponge species present along the island's coasts was carried out for the first time. Analysis of rhodoliths trapped in nets used by local fishermen at two sites and data obtained from underwater video images were used to identify 25 sponge taxa, 22 of them at species level. The classes Demospongiae and Homoscleromorpha were present with 24 and 1 species, respectively. Most of the specimens were small-sized and represented by thick crusts or short erect branches. Few specimens were insinuating or excavating. Furthermore, qualitative sampling was performed on Ustica's coralligenous formations, photophilous hard substrates and in marine caves, and the results obtained were added to the literature data. The overall checklist of sponges from Ustica encompassed 97 taxa, 90 named at species level, subdivided into 6 taxa of Calcarea, 3 of Homoscleromorpha and 88 of Demospongiae. Eleven of the species were endemic to the Mediterranean Sea, mainly concentrated on rhodoliths and in marine caves. This research adds a fundamental element to the knowledge of invertebrates associated with rhodoliths, and updates the checklist of sponges colonizing Ustica's waters, facilitating its future monitoring.

Keywords: Porifera; Ustica Island; Mediterranean Sea; rhodolith beds; coralligenous formations; photophilous hard substrates; marine caves.

Esponjas de los lechos de rodolitos del área marina protegida de la isla de Ustica (sur del mar Tirreno), con un inventario completo de la espongofauna de la isla

Resumen: En este trabajo se estudió la fauna de poríferos que coloniza los fondos de rodolitos del área marina protegida de la isla de Ustica. Además, se creó por primera vez un catálogo de las especies de esponjas que se encuentran en el litoral de la isla. El análisis de los rodolitos enredados en las redes de pescadores locales en dos sitios y de los datos obtenidos de las imágenes de video submarino permitieron reconocer 25 taxones de poríferos, 22 de los cuales se identificaron a nivel de especies. Las clases Demospongiae y Homoscleromorpha estuvieron presentes con 24 y 1 especies respectivamente. La mayoría de los especímenes eran de tamaño pequeño y representados por costras gruesas o ramas cortas y erectas. Pocos especímenes eran esponjas insinuantes o excavadoras. Además, se llevaron a cabo muestreos cualitativos en formaciones de coralígeno, en sustratos duros fotofilos y en cuevas marinas de la isla de Ustica, y se añadieron los resultados obtenidos a los datos de la literatura. El inventario total de las esponjas de Ustica incluye 97 taxones, 90 nombrados a nivel de especies, divididos en: 6 taxones de Calcarea, 3 de Homoscleromorpha, 88 de Demospongiae. Once de las especies son endémicas del mar Mediterráneo, concentradas principalmente en fondos de rodolitos y dentro de cuevas marinas. Esta investigación añade un aspecto fundamental al conocimiento de la distribución de los poríferos, en particular los asociados con los rodolitos, y actualiza la lista de esponjas que colonizan los fondos de Ustica, proporcionando herramientas para su monitoreo futuro.

Palabras clave: Porifera; isla de Ustica; mar Mediterráneo; lechos de rodolitos; hábitat de coralígeno; sustratos duros fotófilos; cuevas marinas.

Citation/Como citar este artículo: Longo C., Corriero G., Cardone F., Mercurio M., Pierri C., Nonnis Marzano C. 2020. Sponges from rhodolith beds surrounding Ustica Island marine protected area (southern Tyrrhenian Sea), with a comprehensive inventory of the island sponge fauna. Sci. Mar. 84(3): 297-308. https://doi.org/10.3989/scimar.04991.29A

Editor: M.J. Uriz.

Received: August 20, 2019. Accepted: May 13, 2020. Published: June 8, 2020.

Copyright: (C) 2020 CSIC. This is an open-access article distributed under the terms of the Creative Commons Attribution 4.0 International (CC BY 4.0) License. 


\section{INTRODUCTION}

The marine habitats recently inserted in Annex 1 of the Habitat Directive (92/43/EC) include rhodolith beds (RBs), biogenic bottoms formed by free calcareous nodules mostly composed of unattached coralline algae of different species (Bosellini and Ginsburg 1971). This substrate, formerly known as maërl in the northeast Atlantic (Irvine and Chamberlain 1994), may have a nucleus of non-algal material (e.g. dead coral pieces, shells) and incrustations of other calcified epibionts (Horta et al. 2016). Indeed, due to their three-dimensionality and structural complexity, coralline red algae forming rhodoliths are considered ecosystem engineers that can modify the substrate and multiply habitats in favour of other organisms. The faunal component of the associated biocoenosis includes epibionts living on algal surfaces, cryptic organisms hiding in the crevices and small invertebrates exploiting the sediment pockets present within the rhodolith structure (Gondim et al. 2014).

Scientific interest in these environments started in the second half of the 20th century, when several researchers (Huvé 1956, Jacquotte 1962, Pérès and Picard 1964) pointed out the high species richness of the communities associated with these living substrates. In particular, the animal taxa showing the highest values of species richness and abundance on rhodoliths include molluscs, polychaetes and crustaceans (e.g. Grall et al. 2006, Foster et al. 2007). In the Mediterranean Sea, the diversity of the overall associated assemblage places RBs among the richest communities, after coralligenous bottoms and Posidonia oceanica meadows (Ballesteros 2006, Sciberras et al. 2009).

In comparison with other habitats of the continental shelf, the faunal biodiversity associated with Mediterranean rhodoliths is very high, with about 700 species recorded (Ramos-Esplà and Luque 2008, Basso et al. 2017). Though knowledge of the biology and ecology of these environments has increased considerably in recent times (Riosmena-Rodríguez et al. 2017), the available data should be further increased. In particular, understanding of the composition, structure, distribution and natural variability of Mediterranean RBs is still considered inadequate (Basso et al. 2017).

Poriferans have been frequently reported as conspicuous inhabitants of RBs worldwide (e.g. Birkett et al. 1998, Aguilar et al. 2009), often playing a role in stabilizing the substrate (Ávila et al. 2013, Calcinai et al. 2013). They can also have an important role in the bioerosion of these calcareous substrata (Leal et al. 2012). Research on sponges from RBs has been performed worldwide (Ávila and Riosmena-Rodríguez 2011, Ávila et al. 2013), although these invertebrates have often been neglected in studies of Mediterranean rhodoliths (e.g. Borg et al. 1998, Massa-Gallucci et al. 2006, Sciberras et al. 2009).

The phylum Porifera, with almost 690 species, is one of the most prominent in the Mediterranean Sea, where it represents about $6 \%$ of the metazoan species and accounts for $7.5 \%$ of global sponge biodiversity (Coll et al. 2010, van Soest et al. 2020). Although lit- erature data on Mediterranean poriferan biodiversity refer mainly to the northwestern basin, where most research institutions are located, large unexplored areas still exist in this region. This is the case of the Tyrrhenian Sea, where the sponge fauna has been thoroughly studied in the Gulf of Naples (see review in Pansini and Longo 2008) but elsewhere specific knowledge should be greatly improved.

Bearing in mind that marine scientists consider fundamental the opportunities offered by marine protected areas (MPA) to counter threats to marine ecosystems, the present study focused on the sponge fauna from RBs surrounding the coast of Ustica Island MPA (southern Tyrrhenian Sea), thus contributing to the knowledge of invertebrates associated with rhodoliths on a local and global scale. Furthermore, with the aim of improving knowledge on the distribution of western Mediterranean sponge fauna, the updated checklist of poriferans from Ustica's bottoms is presented here.

\section{MATERIALS AND METHODS}

\section{Study site}

Ustica Island is located in the southern Tyrrhenian Sea, $67 \mathrm{~km}$ north of the coast of Sicily (Fig. 1). It has a volcanic origin and is entirely surrounded by rocky coasts. On the northern slope, sea bottoms progressively degrade up to about $1800 \mathrm{~m}$ from the coastline and are colonized by Posidonia oceanica up to a depth of 40 to $45 \mathrm{~m}$ thanks to the extreme water transparency. In contrast, the southern coast is characterized by a steep slope on which vegetal communities settle. $P$. oceanica appears in scattered meadows until about -35 m, giving way to RBs and other algal communities at greater depths (Mannino et al. 2002). The island is located on the pathway of a minor branch of the Atlantic Current, which exerts its strong influence on local hydrologic and biotic parameters (Sanfilippo et al. 2016).

Ustica Island was designated a marine reserve (now marine protected area, MPA) in 1986. The MPA currently extends for $15 \mathrm{~km}$ around the island, comprising a no-take area (zone A) on the western coast, a middle buffer area (zone B) surrounding the latter, where the MPA authority regulates different activities including fishing, and a peripheral buffer area (zone C) located on the southern coast of the island. In zone $\mathrm{C}$ many activities are allowed, including professional and recreational fishing, under the management of the MPA authority (Sanfilippo et al. 2016).

\section{Rhodolith beds of Ustica Island}

Ustica's RBs are mainly composed of five species of coralline algae showing growth forms ranging from branched to rounded unattached nodules (prâlines or boxworks) with variable density and shape, (Mannino et al. 2002, Giaccone et al. 2018). The whole assemblage, including epiphytic algae, has 117 taxa and is richer than other western Mediterranean RBs, although with a high level of similarity in the floristic list. The 


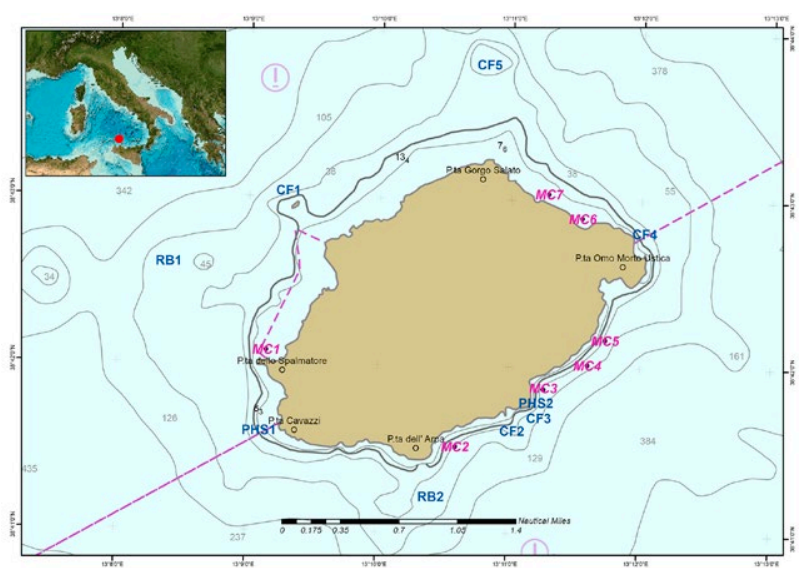

Fig. 1. - Map of Ustica Island with location of the sampling stations. The zonation of the marine protected area is indicated. Sampling stations in the habitats considered are listed below. Rhodolith beds: RB1, off the A zone of the MPA; RB2, off Secchitello Shoal. Coralligenous formations (CF): CF1, Medico Islet; CF2, Galera Cape; CF3, San Paolo Cape; CF4, Omo Morto Cape; CF5, Colombara Shoal. Photophilous hard substrates (PHS): PHS1, Cavazzi Cape; PHS2, Pagliaio Gulf. Marine caves (MC): MC1, Segreta; MC2, Verde; MC3, Barche; MC4, Pastizza; MC5, Azzurra; MC6, Oro; MC7, Colombara.

presence of species typical of other Mediterranean algal communities provides evidence of the transitional position occupied by the algal assemblage from Ustica's RBs (Mannino et al. 2002).

\section{Sponge sampling}

Rhodoliths were collected in the period 1997-2002 at two sites located off the western and southern coast of the island, respectively (RB1 off zone A of the MPA, RB2 on Secchitello Shoal) (Fig. 1), at depths ranging between 70 and $100 \mathrm{~m}$. About $25 \mathrm{~kg}$ of rhodoliths accidentally trapped in trammel nets used by local fishermen with regular fishing authorization were sampled from each site. Additional data were obtained from the analysis of video images taken by divers on transects about $50 \mathrm{~m}$ long carried out at the sampling sites using a Sony XDCAM EX full HD camcorder with professional GATES housing equipped with a GATES full HD monitor, four articulated $80 \mathrm{~cm}$ arms and two Revolution 13000 lumen lights.

\section{Checklist of sponges from Ustica Island MPA}

In addition to RBs, three other types of habitat were taken into consideration for the study of sponge fauna, namely coralligenous formations (CFs), photophilous hard substrates (PHSs) and semi-submerged marine caves (MCs). Qualitative sampling was performed underwater by scuba divers along the coasts of the island (see Fig. 1 for list and location of sampling stations) during the period 20002002. In total, five sampling stations on CFs were considered (Medico Islet, Galera Cape, San Paolo Cape, Omo Morto Cape and Colombara Shoal) at 30 to $40 \mathrm{~m}$ depth. Two stations were considered on PHSs (Cavazzi Cape and Pagliaio Gulf) at 10-15 m depth. Seven MCs were considered (Segreta, Verde,
Table 1. - Main features of the marine caves investigated in the study. The measurements shown are in metres. ${ }^{a}$ Submerged entrance. ${ }^{b}$ Marine cave consisting of two successive cavities connected by a short underwater tunnel. The innermost cavity, completely submerged and difficult to access, was not considered during the present study.

\begin{tabular}{lcccc}
\hline \multirow{2}{*}{ MC } & \multicolumn{2}{c}{ Entrance } & \multicolumn{2}{c}{ Internal } \\
& width & mean depth & total length & max depth \\
\hline MC1: Segreta & 3 & 3 & 5 & 3 \\
MC2: Verde & 15 & 7 & 30 & 5 \\
MC3: Barche & 10 & 4 & 40 & 4 \\
MC4: Pastizza & 1 & 1 & 10 & 6 \\
MC5: Azzurra & 9 & 9 & 25 & 7 \\
MC6: Oro & 6 & 3 & 25 & 5 \\
MC7: Colombara & 1 & 0.5 & 10 & 3 \\
\hline
\end{tabular}

Barche, Pastizza, Azzurra, Oro and Colombara); at each of them qualitative sampling was carried out at the entrance and in the semi-dark and dark zones of the cavity. The main features of the MCs considered in the study are reported in Table 1 . In addition, available literature data regarding sponges from Ustica (Corriero 1989, Corriero et al. 1991, 1996, 1997a, b, 1999) was analysed and revised according to current nomenclature.

\section{Taxonomic analysis}

The sponge specimens were fixed in $4 \%$ formaldehyde and subsequently transferred into $70 \%$ ethanol. Taxonomic identification was accomplished considering external morphology and skeletal features of the sponges using standard techniques to prepare slides of fibres and spicules for light microscopy observation. Body features, spicules and skeletal arrangements were taken into account according to the thesaurus of sponge morphology (Boury-Esnault and Rützler 1997). Specimens were identified to the lowest possible taxonomic level. The most recent sponge systematics was followed (Morrow and Cardenas 2015) and the nomenclature adopted is that reported in the relevant updated checklist of the World Register of Marine Species (WoRMS) (van Soest et al. 2020).

The sponge community was also examined taking into account the growth form of each sampled specimen. Four morphological categories were considered according to Boury-Esnault and Rützler (1997): massive/branching, encrusting, insinuating and excavating.

\section{Statistical analysis}

In order to measure similarities between sponge assemblages living on RBs from different Mediterranean sites (Sitjà and Maldonado 2014, Ordines et al. 2017, Santín et al. 2018), the Jaccard similarity index was applied. To compare the taxonomic structure of sponge assemblages, a matrix of similarities among sampling sites (habitats) was constructed using the Bray-Curtis similarity coefficient. From this matrix, the habitats were classified by principal coordinates analysis. The relationships among the habitats in number of exclusive, shared and endemic species were graphically represented, illustrating the levels of overlap among habitats in species. 
$300 \cdot$ C. Longo et al.

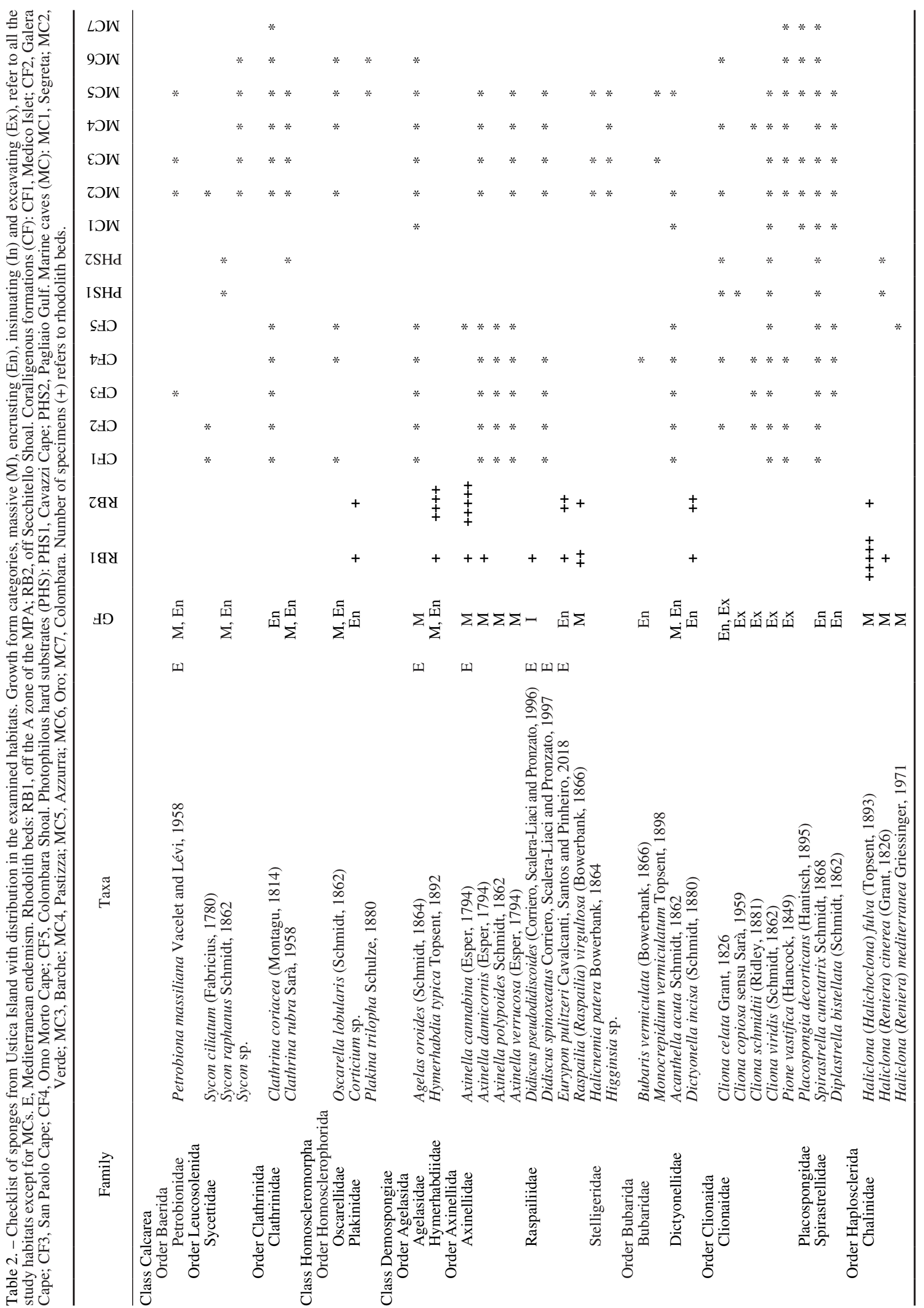




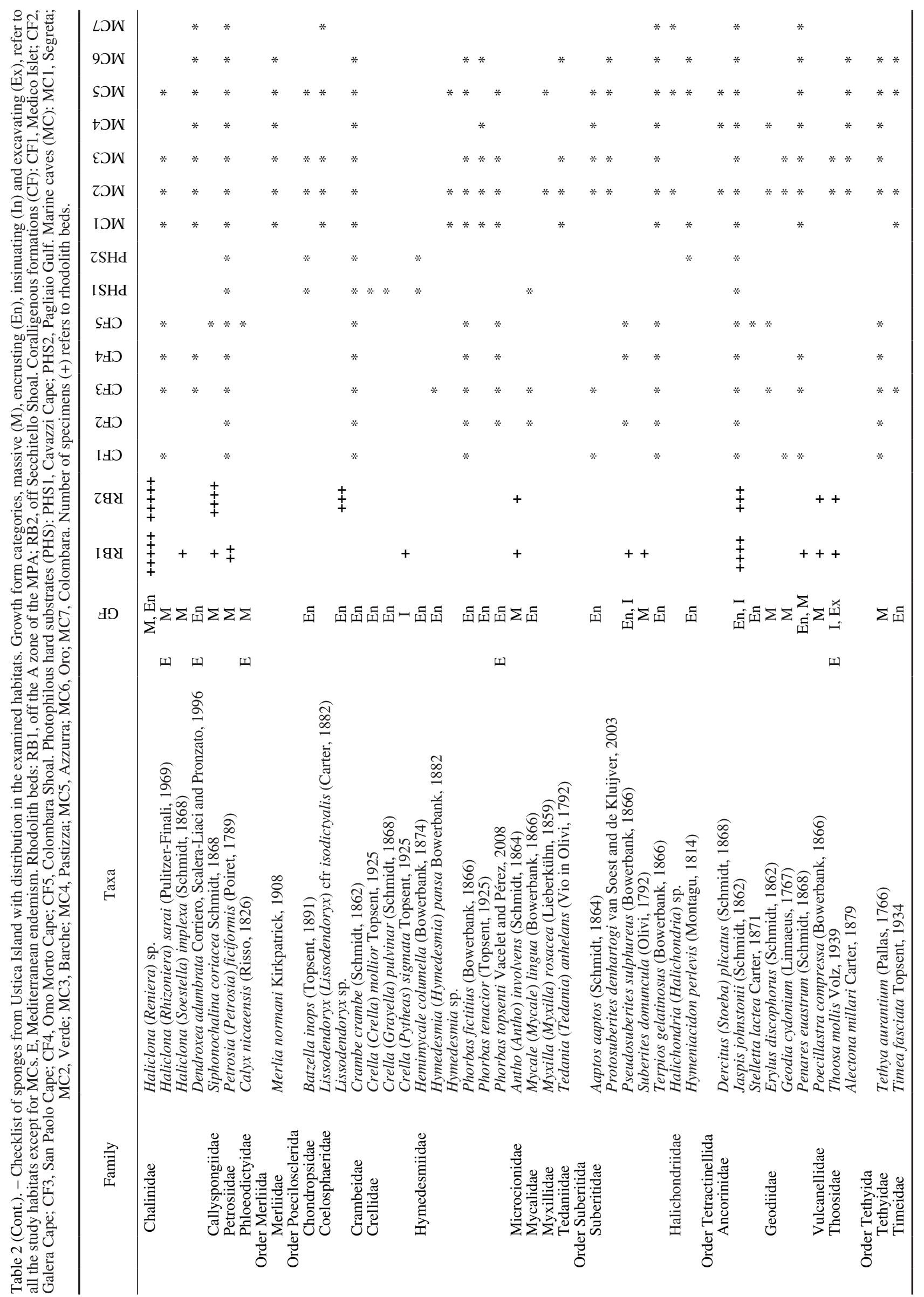




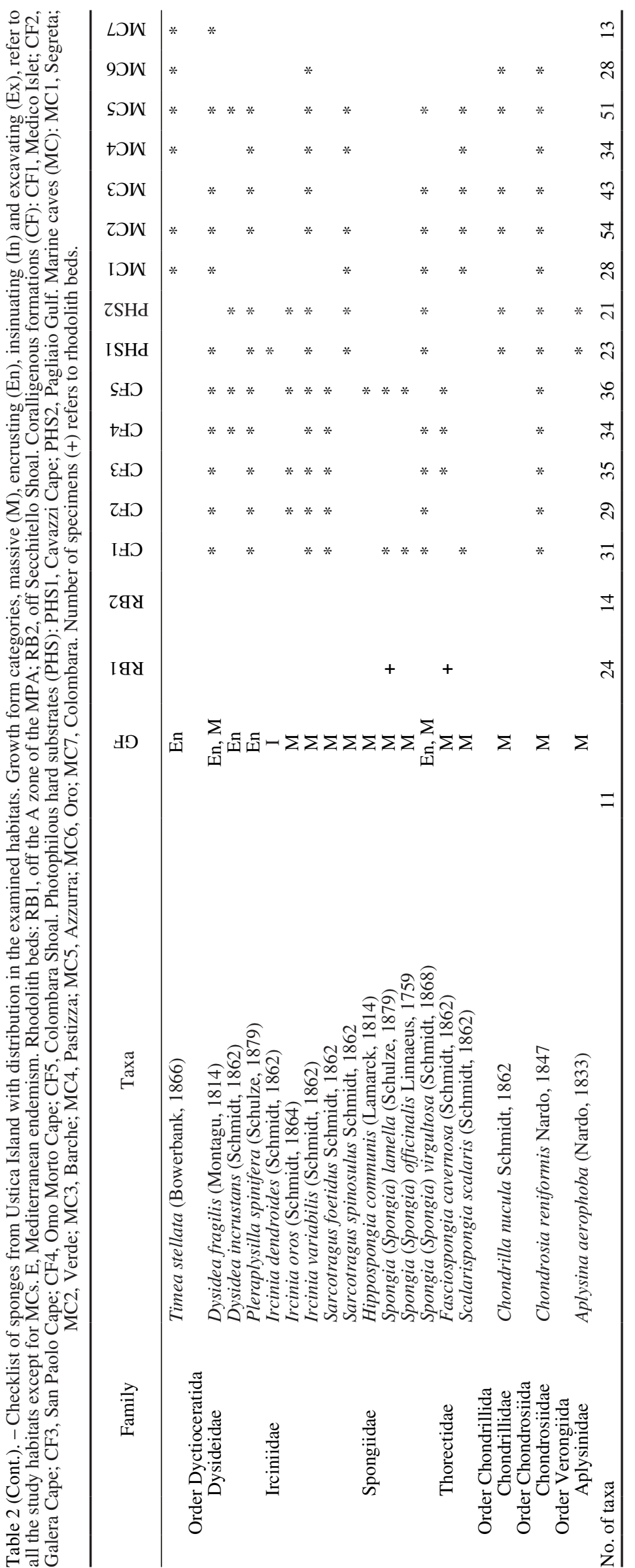

\section{RESULTS}

\section{Sponges from rhodolith beds}

The sponge species recorded from RBs along the coast of Ustica Island are listed in Table 2. A total of 71 specimens belonging to 25 taxa were recorded, and 22 of them (88\%) were identified to species level. The classes Demospongiae and Homoscleromorpha were present with 24 and 1 taxa, respectively. Moreover, demosponges represented more than $97 \%$ of all sponge specimens at both sampling sites. Sponges showed different growth forms: most of them were massive (54.9\%), and encrusting (36.6\%), while few were insinuating and/or excavating $(7.1 \%$ and $1.4 \%$, respectively). Most of the massive species were smallsized, represented by thick crusts or short erect branches, whereas only a few species developed in long digitations (Siphonochalina coriacea) or in large subspherical shape (Suberites domuncula and Fasciospongia cavernosa). Among subspherical specimens, some showed a rolling habitus, namely those belonging to $S$. domuncula and some of those attributable to Haliclona (Reniera) sp., the latter grown on a small central dead rhodolith core. On the whole, massive and encrusting specimens partially or completely overgrew rhodoliths, and two species, Hymerhabdia typica and Lissodendoryx sp., showed the ability of binding rhodoliths together.

Haliclona (Reniera) sp. and Jaspis johnstonii were the most frequent species at both sampling sites, accounting for about $24 \%$ of the specimens recorded. Other frequent species were Haliclona (Halichoclona) fulva and Axinella cannabina, the former prevailing at station RB1, the latter at station RB2, together with $\mathrm{H}$. typica and S. coriacea (Fig. 2, Table 2). On the whole, these six species represented almost 55\% of all the specimens found. The sampling stations showed comparable values of sponge abundance, although species richness was higher at station RB1 (24 vs 14 species, Table 2).

Four (16\%) of the recorded taxa, namely A. cannabina, Didiscus pseudodidiscoides, Eurypon pulitzeri and Thoosa mollis, represented Mediterranean endemic species.

The Jaccard similarity index calculated between sponge assemblages living on RBs from Ustica Island, the Alboran Sea and the Balearic Archipelago (Sitjà and Maldonado 2014, Ordines et al. 2017, Santín et al. 2018) showed values ranging from $4.6 \%$ to $8.3 \%$, the latter referring to Ustica Island versus the Balearic Archipelago. 

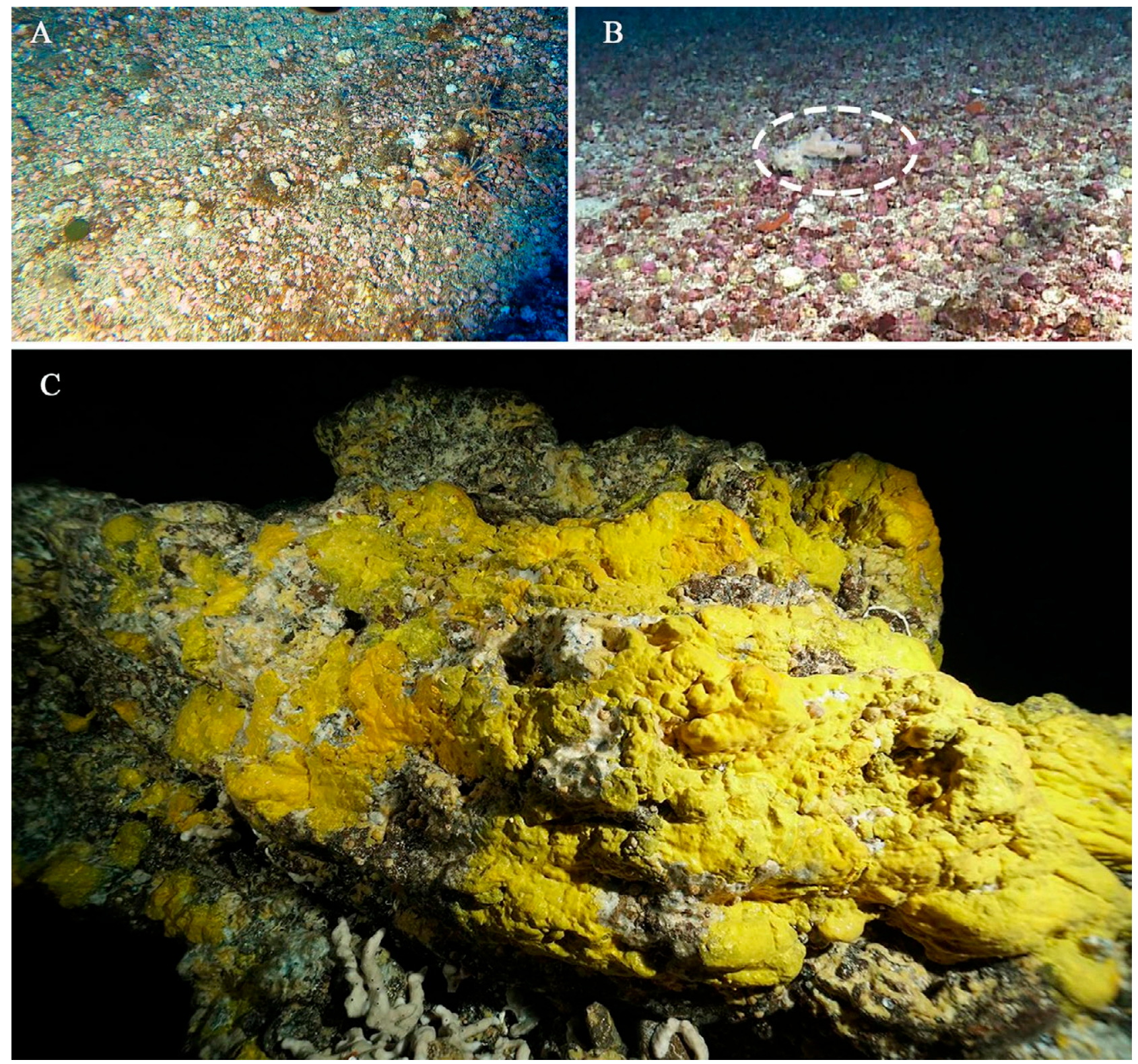

Fig. 2. - Underwater images of rhodolith beds from Ustica's bottoms (A, station RB1; B, station RB2) and an extensive Merlia normani facies in the semi-dark zone of the Verde marine cave (C). In B, the dashed line highlights a specimen of Siphonochalina coriacea.

\section{Checklist of sponges from Ustica Island MPA}

The overall checklist of sponges from Ustica Island (Table 2) encompassed 97 taxa, 90 named at species level, divided as follows: 6 taxa of Calcarea ( 2 subclasses, 3 orders, 3 families, 3 genera), 3 taxa of Homoscleromorpha (1 order, 2 families, 3 genera) and 88 taxa of Demospongiae ( 3 subclasses, 14 orders, 39 families, 63 genera, 18 subgenera) (Table 2). The order Poecilosclerida was the best represented, with 9 families, 11 genera and 17 taxa. Dictyoceratida and Haplosclerida, with 14 and 11 species, respectively, were other representative orders.

On the whole, 11 of the species recorded $(11.3 \%)$ were endemic to the Mediterranean Sea and two of them, namely Calyx nicaeensis and D. pseudodidiscoides, were found at one sampling station only. Considering the whole checklist, 17 species were recorded only once, while among the most frequent species, the only one constantly present at all 16 sampling stations considered was J. johnstonii, Petrosia (Petrosia) ficiformis and Spirastrella cunctatrix were both present at 14 of the 16 stations and Chondrosia reniformis, Crambe crambe, Ircinia variabilis and Terpios gelatinosus were recorded at 12 of the 16 stations.

Among the habitats considered in addition to RBs, MCs hosted the largest number of taxa (59), followed by CFs with 52 and photophilous hard substrates (PHSs) with 27 taxa. As regards sponges from MCs, besides $J$. johnstonii, the species Dendroxea adumbrata, Penares euastrum, $P$. (P.) ficiformis, S. cunctatrix and T. gelatinosus were present at all $7 \mathrm{MCs}$ considered in the study. Eight and 11 species (13.3 and 18.3\%, respectively) were present at 6 and 5 of the MCs, respectively (Table 2).

Species richness of sponge assemblages from the studied MCs ranged from 13 to 54 species depending 

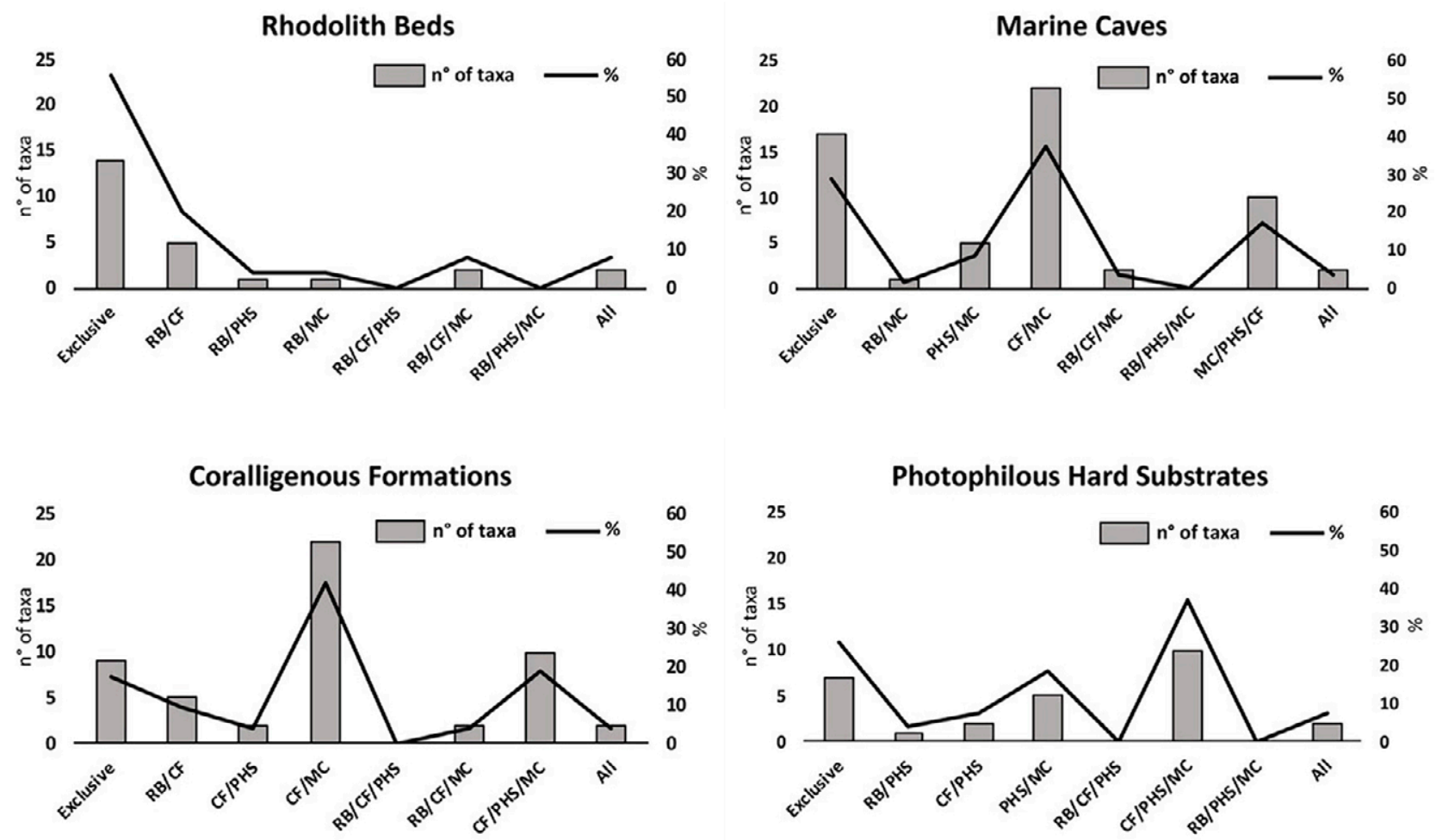

Fig. 3. - Sponge taxa distribution recorded in each habitat and shared across the four studied habitats.

on cave length, entrance width, light and hydrodynamic gradients (Table 1). In particular, the Verde and Azzurra caves (MC2 and MC5, respectively) hosted the highest number of species (54 and 51, respectively) while the Colombara Cave (MC7) hosted only 13 species.

Among the sciaphilous species recorded in the studied MCs, the Mediterranean paleoendemic Calcaronea Petrobiona massiliana and the Heteroscleromorpha Merlia normani, belonging to the family Merliidae, were particularly interesting. The former was recorded in 3 of the 7 MCs studied (MC2, MC3, MC5), while the latter was found in all the caves studied, apart from the smallest, Colombara Cave (MC7), forming large facies with covering values up to $2 \mathrm{~m}^{2}$ in the semi-dark and dark zones of the caves (Fig. 2). Didiscus spinoxeatus, previously described in the Barche and Verde caves of Ustica Island (Corriero et al. 1997a), was found in the present study in two more caves (Table 2). Lastly, $D$. adumbrata, already recorded in the Colombara Cave (Corriero et al. 1996), was found in four other caves and at two stations on CFs (CF3 and CF4, Table 2).

Ninety percent of sponges from CFs showed an encrusting or small massive/branching growth form (about $45 \%$ for each category), while excavating species were less represented (about 7\%).

The sponge assemblage from CFs encompassed a total of 52 species, 9 of them exclusively found in this habitat (Axinella polypoides, Bubaris vermiculata, $C$. nicaeensis, Haliclona (Reniera) mediterranea, Hippospongia communis, Hymedesmia (Hymedesmia) pansa, Sarcotragus foetidus, Spongia (Spongia) officinalis and Stelletta lactea) (Table 2). The five sites studied showed similar values of species richness, ranging from 29 at Galera Cape to 36 at Colombara Shoal. In addition, a conspicuous pool of species $(35.5 \%)$ was shared by all the sites (Table 2). Overall, the sponge assemblage from Ustica's CF included species already known for Mediterranean coralligenous bottoms, with the exceptions of the above-mentioned species $D$. $a d$ umbrata and $S$. coriacea. Regarding Mediterranean endemism, CFs showed the highest number (8) and the highest percentage $(15.4 \%)$ of endemic species.

Over a total of 27 species detected on PHSs, those showing encrusting or massive growth form were the most represented (about 50 and $40 \%$, respectively), while excavating species were rather rare. In this habitat 7 exclusive species were detected (Sycon raphanus, Aplysina aerophoba, Cliona copiosa, Crella (Crella) mollior, Crella (Grayella) pulvinar, Hemimycale columella and Ircinia dendroides), representing about $26 \%$ of the entire sponge assemblage. Moreover, four of them were exclusively found at Cavazzi Cape (Table 2 ). Noteworthy is the small size (a few centimetres) of the massive species, mainly found on scattered rocks or associated with the thalli of Cystoseira spp.

The species distribution among different habitats is reported in Figure 3, which shows the number of species exclusive to a single habitat or shared among different habitats. Among the four habitats considered, the highest number of exclusive species was recorded in MCs (15 species, corresponding to about $25 \%$ of the MC assemblage), though the highest percentage was registered on RBs $(56 \%=14$ species $)$, hosting two endemic exclusive species (D. pseudodidiscoides and E. pulitzeri). RBs showed the highest species overlap with CFs (nine species, corresponding to $13.2 \%$ of the total assemblage present in these habitats) (Fig. 3). 


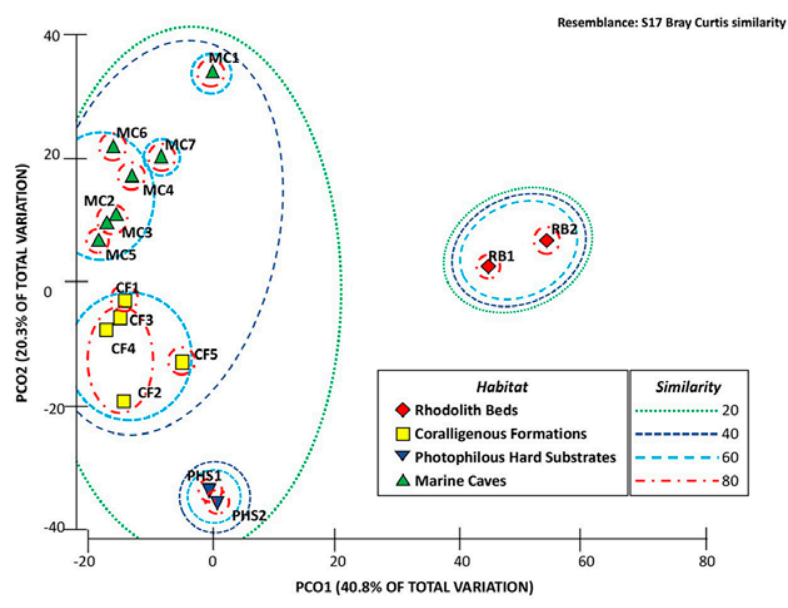

Fig. 4. - Principal coordinates analysis based on a Bray-Curtis similarity resemblance matrix on untransformed data of sponge assemblages from the studied habitats.

The cluster analysis showed a clear distribution pattern of sponge species within the habitats. In particular, the principal component analysis highlighted an early separation between the sponge assemblage from RBs and those colonizing the other habitats (Fig. 4). The PHS assemblages showed a clear separation from CFs and MCs, while the latter, though separate from each other, were generally characterized by higher similarity values (almost 60\%). Moreover, the sponge assemblages from two of the seven studied MCs (MC1 and MC4, both with submerged entrance) were grouped closer to CFs than those from the remaining MCs.

\section{DISCUSSION}

\section{Sponge fauna associated with rhodolith beds}

RBs are the subject of a special protection plan conceived in the context of the United Nations Mediterranean Action Plan (Agnesi et al. 2009, UNEPMAP-RAC/SPA 2017), which however is not binding on national governments. In particular, fundamental goals that must be achieved to safeguard RBs are to implement their inventory in the Mediterranean area, in order to better assess their extent, their state of health and threats to their survival, and to improve the checklist of associated species with the aim of promoting a regular monitoring of these environments (Basso et al. 2016, 2017).

International studies on the fauna associated with RBs show high values of species diversity in all the seas (e.g. Neill et al. 2015, Hernandez-Kantun et al. 2017), including the Mediterranean. Here in particular, high values of biodiversity were already reported more than 50 years ago (Jacquotte 1962, Picard 1965), and more recently several studies (Sciberras et al. 2009, Calcinai et al. 2013, Basso et al. 2017) have recorded about 350 animal species on Mediterranean RBs. As regards sponges, apart from some incomplete data on the southeastern Spanish Mediterranean coast (BIOMAËRL team 1999), only recently some studies carried out on the western Mediterranean deep shelf have provided information on the sponge fauna associated with local RBs (e.g. Calcinai et al. 2013, Ordines et al. 2017, Santín et al. 2018).

In this scenario, the present study allowed us to identify 25 sponge taxa associated with RBs surrounding Ustica Island, 19 of them $(76 \%)$ representing new records for the checklist of sponges from Mediterranean RBs. The list is therefore updated to 91 taxa, with an increase of more than $26 \%$. Moreover, from the comparison among the sponge assemblages from Mediterranean RBs, it emerges that the percentage of species exclusive to each site ranges between $60 \%$ off the coast of Alicante (Ordines et al. 2017, Santín et al. 2018) and 83\% in the Alboran Sea (BIOMAËRL team 1999, Calcinai et al. 2013, Sitjà and Maldonado 2014), coherently with what was found for Ustica's rhodoliths. This confirms that the results achieved by research in the Mediterranean are still far from reaching a plateau, and further studies are needed to acquire an appropriate knowledge of sponges colonizing $\mathrm{RBs}$ in this area.

Predictably, the similarity between sponge assemblages colonizing RBs from Ustica Island, the Alboran Sea and the Balearic Archipelago showed rather low values, even though such sites are all located in the western Mediterranean basin. This result reveals the considerable diversification of sponge assemblages associated with Mediterranean RBs and is in agreement with previous studies conducted along Mexican coasts (e.g. Ávila and Riosmena-Rodríguez 2011), which recorded a certain variability between sponge assemblages from RBs a few kilometres from each other. In contrast, other studies (e.g. Teichert et al. 2014) reported faunal communities associated with polar RBs to be more similar to each other.

On the whole, variability in species diversity and abundance of the associated community across RBs is related to rhodolith complexity and size, which control microhabitat diversification (Grall and Glémarec 1997), but also to other ecological factors associated with larval recruitment and the impact of human activities (Ávila and Riosmena-Rodríguez 2011). In this scenario, the greatest coralline diversity recorded for rhodoliths of temperate regions (Hernandez-Kantun et al. 2017), and in particular the much higher values reported for Mediterranean rhodoliths than for those of the northeast Atlantic (Basso et al. 2017), are probably responsible for a greater internal diversification of Mediterranean RBs and consequently of the associated communities.

The vast majority of the sponge specimens found on Ustica's RBs had a massive and encrusting morphology, and two species showed the ability to bind rhodoliths together, similarly to what has been observed elsewhere (e.g. Ávila and Riosmena-Rodríguez 2011). In fact, the sponge assemblage recorded seems to play primarily a role in substrate construction and stabilization, rather than in its erosion. In particular, boring sponges were represented by only one species (Thoosa mollis) recorded only once at each sampling station, and almost all sampled rhodoliths were lacking in erosion scars. 
The lack of excavating sponges on Ustica's rhodoliths was an unexpected result, contrasting with what has been observed in other studies, where boring sponges were found to be considerably more represented, showing an important role in the bioerosion process of rhodoliths (Leal et al. 2012, Ávila et al. 2013). Moreover, several species of perforating sponges were recorded in the other habitats investigated by this research. Interestingly, the literature reports that the clionids, which constituted the vast majority of Ustica's perforating species but were never recorded on RBs, are underrepresented in carbonate structures built by algae (Cerrano et al. 2001), thus supporting our finding.

\section{Checklist of sponges from Ustica Island MPA}

The thorough revision of the available scientific literature on Ustica's sponge fauna (Corriero 1989, Corriero et al. 1991, 1996, 1997a, b, 1999), supplemented by data from the present study, allowed us to draw up the first checklist of the sponge fauna from the MPA of Ustica Island. The study made it possible to add one species (Crella (Crella) mollior) to the list of demosponges previously compiled for the southern Tyrrhenian Sea by Pansini and Longo (2008).

The present list reports the occurrence of Cliona copiosa, though it is considered synonymous to $C$. viridis by Rosell and Uriz (2002). Indeed, the so called " $C$. viridis complex" (Schönberg 2002, Leal et al. 2016) includes many different morphotypes that had been previously considered different species (Sarà 1959, 1961). However, Barbieri et al. (2008) have already pointed out the presence of morphometric, ecological and genetic differences between morphotypes living sympatrically on rocky shores of the Ligurian Sea, suggesting the occurrence of at least two different species within the generally accepted " $C$. viridis complex". During this study, the specimens collected at Cape Cavazzi on PHSs were morphologically very different from the sympatric $C$. viridis, thus suggesting the need to preserve the distinction between the original species.

Mediterranean endemic species were most concentrated on CFs and least on PHSs, in accordance with recent studies performed by this research group, which revealed a high percentage of Mediterranean endemic species (more than 25\%) in the sponge assemblage from Apulian coralligenous outcrops (Longo et al. 2018). On the whole, the richness of sponge fauna from Ustica Island was mainly due to sciaphilous habitats, with MCs and CFs hosting the largest number of taxa and the noteworthy contribution of taxa exclusive to RBs. Indeed, Ustica's rhodoliths showed a peculiar sponge assemblage, with most of the species exclusive to this habitat. This result seems to be in contrast with previous studies performed in the Mediterranean (e.g. Sciberras et al. 2009), in which most of the animal species registered had also been found on other substrates, and species exclusive to RBs, were negligible.

The sponge assemblages investigated consisted mainly of encrusting or small massive/branching specimens on both RBs and the other habitats considered, in contrast with what is reported by Corriero et al. (2004) and Longo et al. (2018), who found a higher percentage of large massive specimens on CFs and PHSs along southern Italian coasts. This result might depend on the rather low trophic level of sea water along the coasts of Ustica (Sanfilippo et al. 2016), which could lead to a lower trophic availability and therefore lower growth rates in filter feeding animals such as sponges.

As regards RBs, previous studies (Ávila and Riosmena-Rodríguez 2011, Ávila et al. 2013) recorded a higher proportion of massive specimens, though the small dimensions of sponges from Ustica's RBs are probably due to the presence on these bottoms of authorized trawling activities. In fact, trawling has been reported to have negative effects on benthic organisms like sponges, which suffer damage after the passage of a bottom trawl gear (see Ordines et al. 2017). In addition, Ustica's RBs are characterized by a noteworthy hydrodynamism (Giaccone et al. 2018), which probably affects the growth form of both coralline algae and sponges.

The sponge assemblage from Ustica's CFs encompassed species already known for Mediterranean coralligenous bottoms (Bertolino et al. 2013, Longo et al. 2018) and appeared to be rather homogeneous, showing a comparable richness among the five sampling stations and a large number of species in common. In addition, this habitat showed rather high similarity values with $\mathrm{MCs}$, whereas the comparison between the sponge assemblages from different habitats gave much lower results in all the other cases. Indeed, similarity values were always lower than $25 \%$ and, in particular, the similarity between RBs and the other habitats were always negligible, ranging between $6.1 \%$ (RB/PHS) and $13.2 \%$ (RB/CF).

In contrast to what was observed on $\mathrm{CFs}$, the sponge assemblage from Ustica's MCs proved to be quite inhomogeneous and diversified at the sampling stations. The rather different values of species richness in the seven MCs studied probably depend on characteristics such as cave length, entrance width and depth, light penetration and hydrodynamic conditions. Indeed, the lowest richness was recorded in caves located along the northern side of the island's coast, which are more exposed to the dominant winds and periodically affected by violent coastal storms. In these caves, hydrodynamism probably acts as a factor of mechanical stress for sponges, reducing their substrate colonization success and limiting the growth of massive and erect specimens (Bell and Barnes 2000). This hypothesis is supported by the prevalence of encrusting or small cushion-shaped specimens in these environments.

The comparison of the sponge assemblage from Ustica's MCs with literature data on Mediterranean MC fauna (Gerovasileiou and Voultsiadou 2012, Grenier et al. 2018) showed that Ustica harbours almost $18 \%$ of the entire sponge assemblage recorded from Mediterranean MCs. With the exception of Clathrina coriacea, all the remaining species registered at Ustica were already known for this environment (Gerovasileiou and Voultsiadou 2012, Grenier et al. 2018, Gerovasileiou et al. 2019). As regards species currently considered 
exclusive to MCs, such as Dendroxea adumbrata and Didiscus pseudodidiscoides (Gerovasileiou and Voultsiadou 2012, Grenier et al. 2018, Gerovasileiou et al. 2019) described for Italian and French coasts (Corriero et al. 1996), during the present study they were also found on CFs and RBs at depths of 3 to 40 and 70 to 80 $\mathrm{m}$, respectively.

Though the island of Ustica has been an MPA since 1986, the study of its coastal habitats is still inadequate and ongoing. In this context, this study adds a fundamental element to the knowledge of the marine fauna that inhabits the island's waters, facilitating its monitoring in the future.

\section{ACKNOWLEDGEMENTS}

The present study was partly financed by Ustica Island MPA, which also authorized the data collection. Special thanks are due to Riccardo Cingillo for underwater images and to Francesco De Giosa for his help in map processing.

\section{REFERENCES}

Agnesi S., Annunziatellis A., Casese M.L., et al. 2009. Analysis on the coralligenous assemblages in the Mediterranean Sea: a review of the current state of knowledge in support of future investigations. In: Pergent-Martini C., Brichet M. (eds), Proceedings of the 1st Mediterranean symposium on the conservation of the coralligenous and other calcareous bio-concretions (Tabarka, 15-16 January 2009). RAC/SPA Publ., Tunis, pp. 41-46.

Aguilar R., Pastor X., De la Torriente A., et al. 2009. Deep-sea coralligenous beds observed with ROV on four seamounts in the Western Mediterranean. In: Pergent-Martini C., Brichet M. (eds), Proceedings of the 1st Mediterranean symposium on the conservation of the coralligenous and other calcareous bio-concretions (Tabarka, 15-16 January 2009). RAC/SPA Publ., Tunis, pp. 148-150.

Ávila E., Riosmena-Rodríguez R. 2011. A preliminary evaluation of shallow-water rhodolith beds of Bahia Magdalena, Mexico. Braz. J. Oceanogr. 59: 365-375. https://doi.org/10.1590/S1679-87592011000400007

Ávila E., Riosmena Rodríguez R., Hinojosa-Arango G. 2013. Sponge-rhodolith interactions in a subtropical estuarine system. Helgoland Mar. Res. 67: 349-357. https://doi.org/10.1007/s10152-012-0327-y

Ballesteros E. 2006. Mediterranean coralligenous assemblages: a synthesis of present knowledge. Oceanogr. Mar. Biol. Annu. Rev. 44: 123-195.

Barbieri M., Bavestrello G., Sarà M. 2008. Morphological and ecological differences in two electrophoretically detected species of Cliona (Porifera, Demospongiae). Biol. J. Linn. Soc. 54: 193-200. https://doi.org/10.1111/j.1095-8312.1995.tb01032.x

Basso D., Babbini L., Kaleb S., et al. 2016. Monitoring deep Mediterranean rhodolith beds. Aquat. Conserv. 26: 549-561. https://doi.org/10.1002/aqc.2586

Basso D., Babbini L., Ramos-Esplá A.A., et al. 2017. Mediterranean rhodolith beds. In: Riosmena-Rodríguez R., Nelson W., Aguirre J. (eds), Rhodolith/Maërl Beds: A Global Perspective. Springer International, Cham, pp. 282-295. https://doi.org/10.1007/978-3-319-29315-8 11

Bell J.J., Barnes D.K.A. 2000. A sponge diversity centre within a marine 'island'. Hydrobiologia 440: 55-64. https://doi.org/10.1007/978-94-017-1982-7 6

Bertolino M., Cerrano C., Bavestrello G., et al. 2013. Diversity of Porifera in the Mediterranean coralligenous accretions, with description of a new species. ZooKeys 336: 1-37. https://doi.org/10.3897/zookeys.336.5139

BIOMAËRL Team. 1999. Final report, BIOMAËRL project (Coordinator: Moore P.O. University Marine Biological Station Millport, Scotland), EC Contract No. MAS3-CT95-0020, 973 pp.
Birkett D.A., Maggs C.A., Dring M.J. 1998. Maërl (volume V). An overview of dynamic and sensitivity characteristics for conservation management of marine SACs. Scottish Association for Marine Science (UK Marine SACs Project), Belfast, 116 pp.

Borg J.A., Howegel H.M., Lanfranco E., et al. 1998. The Macrobenthic Species of the lnfralittoral to Circalittoral Transition Zone off the Northeastern Coast of Malta (Central Mediterranean). Xjenza 31: 16-24.

Bosellini A., Ginsburg R.N. 1971. Form and internal structure of recent algal nodules (rhodolites). Bermuda J. Geol. 79: 669-682. https://doi.org/10.1086/627697

Boury-Esnault N., Rützler K. 1997. Thesaurus of Sponge Morphology. Smithsonian Institution Press, Washington, DC, 55 pp. https://doi.org/10.5479/si.00810282.596

Calcinai B., Moratti V., Martinelli M., et al. 2013. Uncommon sponges associated with deep coral bank and maërl habitats in the Strait of Sicily (Mediterranean Sea). Ital. J. Zool. 80: $412-423$. https://doi.org/10.1080/11250003.2013.786763

Cerrano C., Bavestrello G., Bianchi C., et al. 2001. The role of sponge bioerosion in Mediterranean coralligenous accretion. In: Faranda F.M., Guglielmo L., Spezie G. (eds), Mediterranean Ecosystems. Springer, Milano, pp. 235-240. https://doi.org/10.1007/978-88-470-2105-1_30

Coll M., Piroddi C., Steenbeek J., et al. 2010. The Biodiversity of the Mediterranean Sea: Estimates, Patterns, and Threats. PLoS ONE 5: e11842. https://doi.org/10.1371/journal.pone.0011842

Corriero G. 1989. Primi dati sul popolamento di Poriferi delle grotte superficiali dell'isola di Ustica. Nova Thalassia 10: 585-588.

Corriero G., Pronzato R., Sarà M. 1991. The Sponge Fauna Associated with Arca noae L. (Mollusca, Bivalvia). In: Reitner J., Keupp H. (eds), Fossil and Recent Sponges. Springer, Berlin, Heidelberg, pp. 395-403. https://doi.org/10.1007/978-3-642-75656-6 32

Corriero G., Scalera Liaci L., Pronzato R. 1996. Two new species of Dendroxea Griessinger, 1971 (Porifera, Demospongiae) from the Mediterranean Sea. Bull. Inst. r. Sci. Nat. Belg. 66: 197-203.

Corriero G., Scalera Liaci L., Pronzato R. 1997a. Didiscus spinoxeatus, a new species of Porifera (Demospongiae) from the Mediterranean Sea. Ophelia 47: 63-70. https://doi.org/10.1080/00785326.1997.10433391

Corriero G., Scalera Liaci L., Gristina M., et al. 1997b. Composizione tassonomica e distribuzione della fauna a Poriferi e Briozoi di una grotta semisommersa della Riserva Marina di Ustica. Biol. Mar. Medit. 4: 34-43.

Corriero G., Scalera Liaci L., Gristina M., et al. 1999. Composizione tassonomica e distribuzione del macrozoobenthos in ambienti di grotta semisommersa della Riserva Naturale Marina "Isola di Ustica”. Biol. Mar. Medit. 6: 250-252.

Corriero G., Gherardi M., Giangrande A., et al. 2004. Inventory and distribution of hard bottom fauna from the Marine Protected Area of Porto Cesareo (Ionian Sea): Porifera and Polichaeta. Ital. J. Zool. 71: 237-245 https://doi.org/10.1080/11250000409356578

Foster M.S., Mc Connico L.M., Lundsten L., et al. 2007. Diversity and natural history of a Lithothamnion muelleri-Sargassum horridum community in the Gulf of California. Cienc. Mar. 33: 367-384. https://doi.org/10.7773/cm.v33i4.1174

Gerovasileiou V., Voultsiadou E. 2012. Marine caves of the Mediterranean Sea: a sponge biodiversity reservoir within a biodiversity hotspot. PLoS ONE 7: e39873. https://doi.org/10.1371/journal.pone.0039873

Gerovasileiou V., Martínez García A., Álvarez Noguera F., et al. 2019. World Register of Marine Cave Species (WoRCS). Porifera. Accessed 10 April 2019

ht t p : / w w w. marines pecies.org/worcs/aphia. php? $\mathrm{p}=$ taxdetailsandid $=558$

Giaccone T., Giaccone G., Mannino A.M. 2018. Deep rhodolith beds in the Ustica Island (Sicily, Southern Tyrrhenian Sea): a sedimentary and paleoecological approach. Geogr. Fis. Din. Quat. 41: 47-63.

Gondim A.I., Dias T.L.P., de Souza Duarte R.C., et al. 2014. Filling a knowledge gap on the biodiversity of rhodolith-associated Echinodermata from northeastern Brazil. Trop. Conserv. Sci. 7: 87-99.

https://doi.org/10.1177/194008291400700112

Grall J., Glémarec M. 1997. Biodiversité des fonds de maërl en Bretagne: approche fonctionnelle et impacts anthropogeniques. 
Vie Milieu 47: 339-349.

Grall J., Le Loc'h F., Guyonnet B., et al. 2006. Community structure and food web based on stable isotopes $\left(\delta^{15} \mathrm{~N}\right.$ and $\left.\delta^{13} \mathrm{C}\right)$ analysis of a North Eastern Atlantic maërl bed. J. Exp. Mar. Biol. Ecol. 338: $1-15$.

https://doi.org/10.1016/j.jembe.2006.06.013

Grenier M., Ruiz C., Fourt M., et al. 2018. Sponge inventory of the French Mediterranean waters, with an emphasis on cavedwelling species. Zootaxa 4466: 205-228. https://doi.org/10.11646/zootaxa.4466.1.16

Hernandez-Kantun J.J., Hall-Spencer J.M., Grall J., et al. 2017. North Atlantic rhodolith beds. In: Riosmena-Rodríguez R., Nelson W., Aguirre J. (eds), Rhodolith/Maërl Beds: A Global Perspective. Springer International Publishing, Switzerland, pp. 265-279. https://doi.org/10.1007/978-3-319-29315-8 10

Horta P.A., Riul P., Amado Filho G.M., et al. 2016. Rhodoliths in Brazil: Current knowledge and potential impacts of climate change. Braz. J. Oceanogr. 64: 117-136. https://doi.org/10.1590/S1679-875920160870064sp2

Huvé H. 1956. Contribution à l'étude des fonds à Lithothamnium (?) solutum Foslie (= Lithophyllum solutum (Foslie) Lemoine) de la région de Marseille. Rec. Trav. Stat. Mar. Endoume 18: 105-134.

Irvine L.M., Chamberlain Y.M. 1994. Seaweeds of the British Isles. Vol. 1. Rhodophyta. Part 2B. Corallinales, Hildenbrandiales. Natural History Museum, London, 276 pp.

Jacquotte R. 1962. Etude des fonds de maërl de Méditerranée. Rec. Trav. Stat. Mar. Endoume 26: 141-235.

Leal R.N., Bassi D., Posenato R., et al. 2012. Tomographic analysis for bioerosion signatures in shallow-water rhodoliths from the Abrolhos Bank Braz. J. Coast. Res. 28: 306-309. https://doi.org/10.2112/11T-00006.1

Leal C.V., De Paula T.S., Lôbo-Hajdu G., et al. 2016. Morphological and molecular systematics of the Cliona viridis complex from south-eastern Brazil. J. Mar. Biol. Ass. U.K. 96: 313-322. https://doi.org/10.1017/S0025315415001642

Longo C., Cardone F., Pierri C., et al. 2018. Sponges associated with coralligenous formations along the Apulian coasts. Mar. Biodivers. 48: 2151-2163. https://doi.org/10.1007/s12526-017-0744-X

Mannino A.M., Castriota L., Beltrano A.M., et al. 2002. The epiflora of a rhodolith bed from the Island of Ustica (Southern Tyrrhenian Sea). Flora Medit. 12: 11-28.

Massa-Gallucci A., Cigliano M., Lattanzi L., et al. 2006. Zoobenthos associato a fondi a rodoliti (Corallinales) dell'isola d'Ischia (Mare Tirreno). Biol. Mar. Medit. 13: 194-195.

Morrow C., Cárdenas P. 2015. Proposal for a revised classification of the Demospongiae (Porifera). Front. Zool. 12: 7. https://doi.org/10.1186/s12983-015-0099-8

Neill K.F., Nelson W.A., D’Archino R., et al. 2015. Northern New Zealand rhodoliths: assessing faunal and floral diversity in physically contrasting beds. Mar. Biodivers. 45: 63. https://doi.org/10.1007/s12526-014-0229-0

Ordines F., Ramón M., Rivera J., et al. 2017. Why long term trawled red algae beds off Balearic Islands (western Mediterranean) still persist? Reg. Stud. Mar. Sci. 15: 39-49. https://doi.org/10.1016/j.rsma.2017.07.005
Pansini M., Longo C. 2008. Porifera. Biol. Mar. Medit. 15: 42-66.

Pérès J.M., Picard J. 1964. Nouveau manuel de Bionomie bentique de la Mer Méditerranée. Rec. Trav. Stat. Mar. Endoume 31: 5-137.

Picard J. 1965. Recherches qualitatives sur les biocoenoses des substrats meubles dragables de la région marseillaise. Rec. Trav. Stat. Mar. Endoume 52: 3-160.

Ramos-Esplà A.A., Luque del Villar A.A. 2008. Maërl beds: a fragile oasis of marine life. In: The Seas of Spain. Ministerio de Medio Ambiente y Medio Rural y Marino, Madrid, pp. 273-290.

Riosmena-Rodríguez R., Nelson W., Aguirre J. 2017. Rhodolith/ maërl beds: a global perspective. Springer International Publishing, Switzerland, $368 \mathrm{pp}$. https://doi.org/10.1007/978-3-319-29315-8

Rosell D., Uriz M.J. 2002. Excavating and endolithic sponge species (Porifera) from the Mediterranean: species descriptions and identification key. Org. Divers. Evol. 2: 55-86. https://doi.org/10.1078/1439-6092-00033

Sanfilippo M., Capillo G., Spanò N., et al. 2016. Evaluation of Water Variables in No-Take Zone of Ustica Marine Protected Area (Southern Tyrrhenian Sea). Braz. Arch. Biol. Techn. 59: 1-10. https://doi.org/10.1590/1678-4324-2016160330

Santín A., Grinyó J., Ambroso S., et al. 2018. Sponge assemblages on the deep Mediterranean continental shelf and slope (Menorca Channel, Western Mediterranean Sea). Deep-Sea Res. Part I 131: 75-86. https://doi.org/10.1016/j.dsr.2017.11.003

Sarà M. 1959. Specie nuove di Demospongie provenienti da acque superficiali del golfo di Napoli. Annuario Ist. Mus. Zool. Univ. Napoli 11: 1-22.

Sarà M. 1961. La fauna di Poriferi delle grotte delle isole Tremiti. Studio ecologico e sistematico. Arch. Zool. Ital. 46: 1-59.

Schönberg C.H.L. 2002. Sponges of the Cliona viridis complex: a key for species identification. In: Moosa M.K., Soemodihardjo S., et al. (eds), Proceedings of the 9th International Coral Reef Symposium, vol. 1. International Society of Coral Reef Studies, Bali, Indonesia, pp. 295-300.

Sciberras M., Rizzo M., Mifsud J.R., et al. 2009. Habitat structure and biological characteristics of a maërl bed off the northeastern coast of the Maltese Islands (central Mediterranean). Mar. Biodiv. 39: 251-264. https://doi.org/10.1007/s12526-009-0017-4

Sitjà C., Maldonado M. 2014. New and rare sponges from the deep shelf of the Alboran Island (Alboran Sea, Western Mediterranean). Zootaxa 3760: 141-179. https://doi.org/10.11646/zootaxa.3760.2.2

van Soest R.W.M., Boury-Esnault N., Hooper J.N.A., et al. 2020. World Porifera Database. Accessed 25 February 2020. http://www.marinespecies.org/porifera

Teichert S., Woelkerling W., Rüggeberg A., et al. 2014. Arctic rhodolith beds and their environmental controls (Spitsbergen, Norway). Facies 60: 15-37. https://doi.org/10.1007/s10347-013-0372-2

UNEP-MAP-RAC/SPA. 2017. Action Plan for the Conservation of the Coralligenous and Other Calcareous Bio-concretions in the Mediterranean Sea. United Nations Environment Programme/ Mediterranean Action Plan, Athens, Greece, 20 pp. 